ABDI: Jurnal Pengabdian dan Pemberdayaan Masyarakat ISSN: 2656-369X (Print), 2684-8570 (Online)

Volume 3 No. 2, Desember 2021

http://abdi.ppj.unp.ac.id/index.php/abdi

Email: abdi@ppj.unp.ac.id

DOI: https://doi.org/10.24036/abdi.v3i2.203

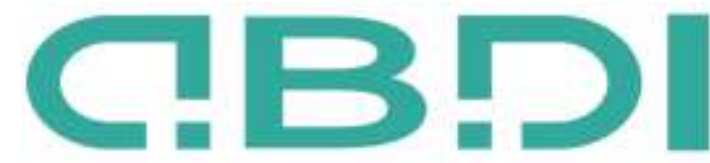

ABDL: JURNAL PENGABDIAN DAN PEMBERDAYAN MASYARAKAT

\title{
Penyuluhan Kewirausahaan Sosial dan Penguatan Kelompok UMKM Dalam Upaya Peningkatan Pemasaran Masa Pandemi Covid-19 di Desa Burai Ogan Ilir
}

\author{
Shomedran', Evy Ratna Kartika Waty², Azizah Husin ${ }^{3}$, Dian Sri Andriani ${ }^{4}$ \\ 1,2,3,4 Universitas Sriwijaya
}

Email: shomed16ut@gmail.com

\begin{abstract}
Abstrak
Kegiatan pengabdian masyarakat ini bertujuan untuk memberikan pengetahuan dan pemahaman masyarakat tentang kewirausahaan sosial dan pentingnya kelompok dalam upaya peningkatan pemasaran bagi pelaku UMKM di Desa Burai Ogan Ilir. Bentuk kegiatan dilakukan dengan metode penyuluhan secara langsung dengan memberikan ceramah, tanya jawab, diskusi, dan pemecahan masalah terhadap kasus pemasaran produk UMKM. Adapun tahapan kegiatan yaitu pemberian pre test, dilanjutkan pemaparan materi tentang kewirausahaan sosial dan penguatan kelompok dan akhiri dengan evaluasi kegiatan dan post test. Peserta kegiatan adalah ibu rumah tangga dan perempuan yang memiliki usaha rumahan tenun songket berjumlah 23 orang. Hasil dari kegiatan ini menunjukkan presentase pemahaman peserta yang meningkat sebelum kegiatan dan sesudah kegiatan, dengan rata-rata presentase 36\% menjadi $75 \%$ setelah kegiatan. Melalui pemahaman peserta terhadap pentingnya wirausaha, komunitas, dan pemasaran masa pandemi diharapkan pemasaran produk yang dihasilkan akan lebih meningkat.
\end{abstract}

Kata Kunci: Kewirausahaan Sosial, Kelompok UMKM, Pemasaran.

Abstract

This community service activity aims to provide knowledge and understanding of the community about social entrepreneurship and the importance of groups in an effort to increase marketing for MSME actors in Burai Ogan Ilir Village. The form of activity is carried out by direct counseling methods by giving lectures, questions and answers, discussions, and problem solving on the case of marketing MSME products. The stages of the activity are giving a pre-test, followed by the presentation of material on social entrepreneurship and group strengthening and ending with an evaluation of activities and a post-test. Participants in the activity are housewives and women who have a home business of songket weaving, totaling 23 people. The results of this activity showed that the percentage of participants' understanding increased before the activity and after the activity, with an average percentage of $36 \%$ to $75 \%$ after the activity. With the participants' understanding of the importance of entrepreneurship, community and marketing during the pandemic, it is hoped that the marketing of the products produced will increase further.

Keywords: Social Entrepreneurship, MSME Group, Marketing.

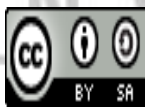




\section{Pendahuluan}

Upaya meningkatkan taraf perekonomian nasional seperti sekarang ini, salah satunya adalah pemberdayaan masyarakat melalui program usaha sektor rumahan (Home Industry) dan UMKM. Sektor ini merupakan salah satu usaha yang dapat memperluas lapangan kerja dan berperan dalam proses peningkatan pendapatan masyarakat atau keluarga, bahkan di saat seperti saat ini usaha kecil rumahan mampu mendorong pertumbuhan ekonomi nasional. Pemerintah terus mendorong sektor Home Industry dan UMKM sehingga diharapkan mampu menyerap banyak lapangan kerja dan akan menguatkan perkonomian secara nasional.

Salah satu upaya yang dilakukan untuk meningkatkan taraf hidup masyarakat ialah dengan melaksanakan berbagai program peningkatkan kualitas sumber daya manusia, seperti hal nya program pada pemberdayaan masyarakat sektor UMKM. Pemberdayaan secara singkat dapat diartikan sebagai upaya untuk memberikan kesempatan dan kemampuan kepada kelompok masyarakat untuk berpartisipasi, bernegoisasi, mempengaruhi, dan mengendalikan kelembagaan masyarakat secara bertanggung jawab demi perbaikan kehidupannya. Masyarakat pada akhirnya akan memperoleh daya dan kekuatan untuk dapat menjalankan kehidupannya (Shomedran, 2016).

Pemberdayaan masyarakat bertujuan agar dapat memberikan daya (kekuatan) bagi masyarakat yang di berdayakan untuk dapat hidup secara mandiri, mengembangkan potensi yang mereka miliki sebagai upaya untuk meningkatkan kualitas sumber daya manusia yang ada. Pemberdayaan masyarakat sendiri merupakan upaya untuk memandirikan masyarakat, lewat perwujudan potensi kemampuan yang mereka miliki. Begitupun dengan tujuan dalam pemberdayaan UMKM, yaitu untuk mengembangkan kemampuan UMKM menjadi usaha yang mendiri dan tangguh, meningkatkan peranan dari UMKM tersebut dalam pembangunan daerah, penciptaan lapangan kerja, dan pertubuhan ekonomi, serta mewujudkan struktur perekonomian nasional yang seimbang, berkembang, dan adil (Mulyadi, dalam Florita et al., 2018). Akan tetapi, tidak dipungkiri di masa pandemi seperti saat ini semua aspek kehidupan menjadi berubah. Salah satu sektor yang terdampak adalah sektor usaha kecil/usaha rumahan, seperti sekarang ini dituntut untuk bisa beradaptasi dengan kebiasaan baru masyarakat, sehingga diharapkan dapat bertahan dan tetap beroperasi seperti biasa sehingga tetap menghasilkan finansial guna mendapatkan masukan perekonomian keluarga.

Program pemberdayaan masyarakat di laksanakan di daerah-daerah seperti halnya salah satu desa yang ada di Kabupaten Ogan Ilir yaitu desa Burai. Desa ini merupakan salah satu Desa dari 21 Desa yang ada di Kecamatan Tanjung Batu, yang terletak sekitar $10 \mathrm{~km}$ kearah Selatan dari Kecamatan Tanjung Batu. Desa Burai memiliki luas wilayah sekitar $\pm 39,52 \mathrm{Km} 2$. Desa Burai memliki jumlah penduduk kurang lebih 2103 jiwa yang tersebar dalam 6 wilayah Dusun. Letak geografis Desa Burai yang berupa perairan dan dataran sehingga sebagian besar penduduknya bermata pencaharian sebagai pengrajin, petani, buruh tani dan nelayan (Monograf Desa Burai, 2020).

Desa Burai adalah salah satu Desa dengan penduduk cukup banyak menjadi pengrajin songket khas Burai, masyarakat Desa Burai sangat terampil dalam usaha pembuatan kain songket. Umumnya setiap wanita dewasa di Desa Burai memiliki keterampilan menenun, bahkan hampir keseluruhan wanita dewasa yang belum menikah dan putus sekolah sekarang pekerjaannya adalah bertenun. Tanpa dipungkiri Desa Burai sekarang ini banyak kita jumpai pelaku UMKM terutama bidang tenun songket khas daerah tersebut.

Budaya tenun merupakan tradisi turun-temurun masyarakat Desa Burai. Para pengrajin tenun Songket sampai saat ini masih menjalankan tradisi menenun. Para perempuan pengrajin kain tenun membagi waktunya antara mengurus keluarga dan membuat kain tenun, hal ini mereka lakukan untuk mengisi waktu luang dan untuk membatu mencukupi perekonomian keluarga. Banyak sekali ragam motif kain songket yang di buat oleh para pengrajin songket di desa burai, seperti motif lepus, motif kembang cina, dan desa burai sendiri juga sudah membuat motif tenun songket khas desa yang dinamakan motif ikan sepatung, yang setiap motif songket tersebut memiliki harga jual yang berbeda sesuai dengan tingkat kerumitan saat proses menenunnya. UMKM Songket merupakan salah satu sentra kerajinan tenun tradisional yang menghasilkan berbagai jenis produk. Sebagaimana pembuatan produk dengan menggunakan bahan dasar tenun songket meningkatkan potensi kreatif kerajinan

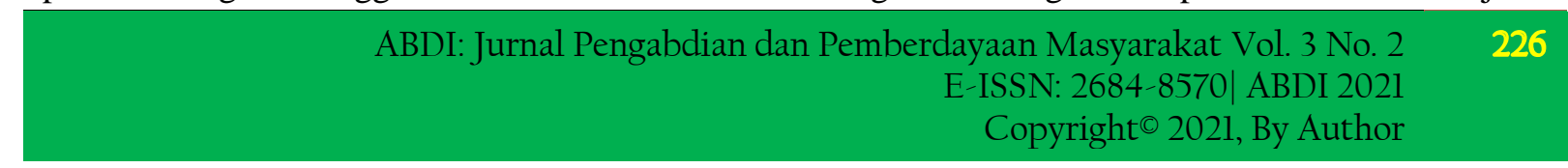


tradisional yang bisa menghasilkan beragam produk fungsional dengan nilai budaya yang kuat terkandung di dalamnya (Efridiyanti et al., 2021).

Kain tenun Songket khas burai memiliki nilai budaya yang ekonomis karena hasil penjualan dari kain tenun Songket dapat menopang kebutuhan hidup para pengrajin songket. Selain itu, tenun Songket juga memiliki nilai estetika yang tinggi dari beragam motif yang dihasilkan. Kepedulian masyarakat Desa Burai terhadap kelangsungan usaha tenun Songket diwujudkan dalam tindakan nyata, salah satunya dengan berupaya melestarikan tenun dengan menghasilkan berbagai kreasi motif dan pembaharuan dalam hal kualitas. Desa Burai merupakan salah satu daerah yang melestarikan dan mengembangkan kerajinan tradisional kain songket. Bahkan saat ini Desa Burai sudah menjadi sentra kerajinan tenun songket wilayah Ogan Ilir.

Banyaknya masyarakat Desa Burai yang memiiki pekerjaan sebagai pengrajin tenun songket, maka perlu adanya tindakan dari pemerintah desa burai yang termasuk perangkat desa untuk membantu dan memberdayakan para masyarakatnya dalam hal ini para pengrajin tenun songket, agar para pengrajin songket yang ada di desa burai dapat lebih mengembangkan potensi mereka, dan dapat mempertahankan kelangsungan usaha tenun songket yang sudah lama mereka jalankan guna membantu perekonomian keluarga dan mempertahankan kelestarian budaya.

Selama ini hasil dari tenun tersebut belum begitu maksimal dalam proses pemasaran seperti dengan perkembangan digital yaitu menggunakan media online. Pada masa pandemi Covid-19 sekarang ini sangat berdampak bagi pelaku UMKM di desa Burai baik secara individu dan kelompok, terlebih untuk pengunjung secara langsung dan pemasarannya yang menurun. Sebelumnya proses pemasaran dilakukan dengan cara mengikuti pameran, ada orang datang berkunjung, melalui teman dari mulut ke mulut sehingga belum maksimal. Untuk itu di saat pandemi seperti ini sangat diperlukan sebuah terobosan dalam proses penjualan produk. Akan tetapi dengan kondisi tersebut sehingga pengusul bermaksud untuk melakukan penyuluhan terkait pentingnya kewirausahaan sosial dan penguatan bagi kelompok bagi pelaku UMKM pengrajin tenun songket dalam upaya agar tetap meningkatkan daya jual, sehingga tetap dapat memperoleh penghasilan yang mencukupi dan dapat berusaha secara terus menerus meskipun dilanda pandemi. Sejalan dengan yang dikemukakan Utomo (2014) bahwa wirausaha sosial melihat masalah sebagai peluang untuk membentuk sebuah model bisnis baru yang bermanfaat bagi pemberdayaan masyarakat sekitar, dengan kondisi tersebut artinya dapat membuat terobosan permasalahan perekonomian masyarakat melalui berwirausaha. Oleh karena itu, kegiatan ini sangat diperlukan bagi pelaku ekonomi terutama di saat pandemi seperti sekarang ini untuk tetap menjaga stabilitas pemasaran produk yang dibuat sehingga akan terus menopang pendapatan dan perkonomian keluarga.

\section{Model dan Metode Kegiatan}

Model kegiatan pengabdian yang dilakukan berupa penyuluhan dan pelatihan pemberdayaan. Proses penyuluhan yang dilakukan menggunakan metode pembelajaran secara variatif dengan ceramah, tanya jawab, dan praktik (demonstrasi) dengan pendekatan metode pembelajaran partisipatif. Adapun tahapan metode tersebut antara lain:

\subsection{Penyuluhan}

Pada pelaksanaan penyuluhan dengan penyampaian materi menggunakan sarana mitra dalam hal ini adalah Desa Burai Kabupaten Ogan Ilir. Adapun penyampaian materi melalui penyuluhan pemberdayaan yang dilakukan secara tatap muka langsung (luring) dengan materi terkait kewirausahaan sosial dan pentingnya kelompok UMKM dalam pemasasaran.

\subsection{Pelatihan/pendampingan}

Sebelum kegiatan terlebih dahulu dilakukan evaluasi pemahaman awal peserta dan diakhir juga dengan evaluasi akhir kegiatan. Hal ini untuk melihat sejauh mana tingkat pencapaian kegiatan bagi peserta kegiatan pengabdian pada masyarakat. Pada kegiatan pelatihan ini yaitu peserta di ajak untuk mengetahui dan mencoba dalam mengenal berbagai media sosial dalam pemasaran produk UMKM. 


\section{Hasil dan Evaluasi}

Kegiatan pengabdian ini dilakukan secara langsung dengan menyampaikan materi kepada peserta yang merupakan masyarakat pengrajin songket di Desa Burai Ogan Ilir Sumatera Selatan. Peserta pada kegiatan ini berjumlah 23 orang yang merupakan masyarakat pengrajin tenun songket. Kegiatan dilakukan dengan bentuk penyuluhan langsung, oleh tim pengabdian yang terdiri atas empat orang dosen dan dua orang mahasiswa. Kegiatan berjalan dengan lancar meskipun di tengah pandemi, dimana kegiatan ini dilakukan dengan mematuhi protokol kesehatan yang ketat. Peserta kegiatan cukup antusias menyaksikan dan menyimak materi yang disampaikan. Berikut adalah bukti kegiatan sebagai hasil dari pengabdian pada masyarakat, terlihat pada gambar di bawah ini:

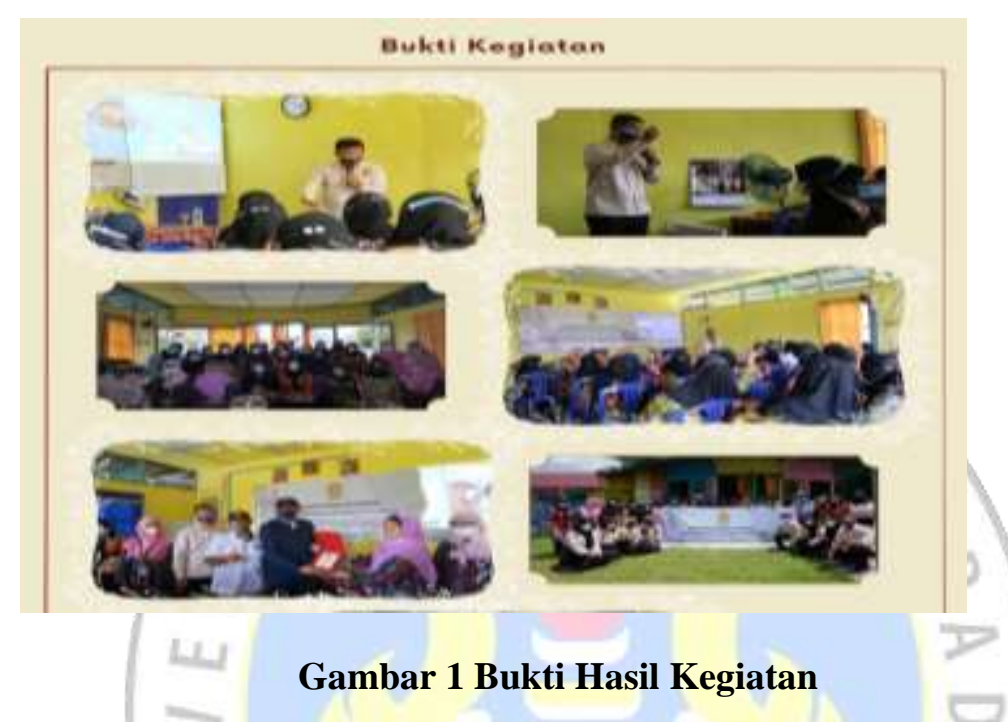

Evaluasi dilakukan melalui kegiatan pre test dan post test, hal ini dilakukan untuk mengetahui tingkat pemahaman peserta terkait materi yang disampaikan. Adapun hasil evaluasi kegiatan pengabdian masyarakat ini dapat dilihat pada tabel berikut:

Tabel 1. Presentase Hasil Pre Test dan Post Test terhadap Pemahaman Warga Belajar/Peserta Penyuluhan

\begin{tabular}{clcc}
\hline No & \multicolumn{1}{c}{ Aspek Evaluasi } & Hasil Pretest & Hasil Postest \\
\hline 1 & $\begin{array}{l}\text { Pemahaman tentang } \\
\text { Kewirausahaan sosial dan }\end{array}$ & $68 \%$ \\
\hline 2 & $\begin{array}{l}\text { PMKM } \\
\text { Pemahaman Penggunaan dan } \\
\text { kepemilikan akun Media sosial }\end{array}$ & $42 \%$ & $82 \%$ \\
\hline 3 & $\begin{array}{l}\text { Pemahaman menggunakan media } \\
\text { sosial untuk usaha }\end{array}$ & $40 \%$ & $80 \%$ \\
\hline 4 & $\begin{array}{l}\text { Pengalaman mengkuti kegiatan } \\
\text { Penyuluhan/pemberdayaan }\end{array}$ & $30 \%$ & $70 \%$ \\
\hline & Rata-rata & $36 \%$ & $75 \%$ \\
\hline
\end{tabular}

Sumber: diolah dari hasil evaluasi (2021)

Berdasarkan tabel di atas dapat diektahui pemahaman dan pengetahuan peserta kegiatan penyuluhan mengalami peningkatan setelah mengikuti kegiatan. Hal ini terlihat dari presentase kegiatan pre test dan post test yang dilakukan. Kegiatan penyuluhan dan pemberdayaan ini dapat menambah pengetahuan dan pengalaman baru pagi peserta. Pemahaman tentang penggunaan media sosial sebagai bentuk pemasaran online guna mengingkatkan pendapatan dari hasil penjualan produk

$$
\begin{array}{r}
\text { ABDI: Jurnal Pengabdian dan Pemberdayaan Masyarakat Vol. } 3 \text { No. } 2 \\
\text { E-ISSN: 2684-8570| ABDI } 2021 \\
\text { Copyright }{ }^{\circledR 2021, ~ B y ~ A u t h o r ~}
\end{array}
$$


UMKM. Sebagaimana bentuk lain pemasaran ini dapat dikatakan pemasaran dengan menggunakan penerapan teknologi secara digital, bentuk marketing digital dengan menggunakan media elektronik atau internet adalah internet marketing (Febriani, 2021).

\section{Pembahasan}

Tujuan yang ingin dicapai dalam kegiatan pengabdian pada masyarakat dengan tema "Penyuluhan Kewirausahaan Sosial dan Penguatan Kelompok UMKM dalam upaya Peningkatan Pemasaran Masa Pandemi Covid-19 di Desa Burai Ogan Ilir" adalah mendukung program perguruan tinggi untuk berpartisipasi dalam usaha mempersiapkan manusia yang berdaya melalui kegiatan sosialisasi dan pemberdayaan. Selain itu, tujuan lain yang ingin dicapai yaitu pemberian pemahaman dan pengetahuan kepada masyarakat tentang kewirausahaan sosial dan kelompok dalam usaha yang dijalankan, yakni pelaku UMKM tenun songket. Di samping itu, kegiatan ini adalah untuk memberdayakan masyarakat pengrajin tenun songket yang berjumlah 23 orang, agar menjadi masyarakat yang mampu memproduksi dan memasarkan produk yang mereka buat secara online guna meningkatkan pemasaran dan pendapatan walaupun di saat pandemi sekarang ini. Pemberdayaan dan pengembangan Usaha Mikro, Kecil dan Menengah (UMKM) merupakan upaya yang ditempuh pemerintah untuk mengatasi masalah pengangguran dan kemiskinan (Prasetyo, 2018).

Kegiatan ini sepenuhnya dilakukan secara langsung dengan melibatkan peserta dari masyarakat desa Burai Ogan Ilir, dimulai dengan kegiatan pembukaan hingga penyampaian materi serta evaluasi, kegiatan dilakukan dengan mematuhi protokol kesehatan, mengingat kondisi dimasa pandemi Covid-19. Adapun proses kegiatan yang dilakukan dengan melakukan berbagai tahapan, yaitu:

\subsection{Tahap Persiapan}

Pada tahap ini dilakukan berbagai kegiatan diantaranya penetapan tempat pengabdian didasarkan pertimbangan bahwa mitra yang dipilih adalah untuk dipersiapkan menjadi contoh terkait implementasi sistem pemasaran dari rumah bagi pengrajin tenun songket, di sisi lain mendapat izin dari pihak berwenang, memiliki narasumber teknis sesuai kebutuhan belajar, memiliki fasilitas belajar yang memadai, serta berlokasi relatif tidak jauh dari kediaman (domisili) calon warga belajar atau peserta kegiatan.

\subsection{Penerapan IPTEK}

Penyuluhan tentang kewirausahaan sosial dan penguatan kelompok UMKM ini berupa kegiatan pemberian materi dan demontstrasi/simulasi dengan cara: 1) Membekali kelompok sasaran pemahaman tentang kewirausahaan sosial; 2) Membekali kelompok sasaran terkait pentingnya penguatan kelompok dalam proses pemasaran produk usaha; dan 3) Membekali kelompok sasaran terkait pemahaman dan keterampilan pemanfaatan media sosial dalam penjualan atau pemasaran terutama masa pandemi sekarang ini.

\subsection{Tahap Implementasi}

Penyelenggaraan kegiatan ini tidak lepas dari satu kesatuan antara penyelenggara dengan pihak peserta, oleh karena itu kegiatan ini menjalin kemitraan dengan beberapa pihak terkait. Mitra yang dimaksud adalah Perangkat Desa Burai Kabupaten Ogan Ilir, dan terdapat pelaku-pelaku UMKM yaitu pengrajin songket dari warga setempat. Kegiatan-kegiatan yang dilakukan dengan mitra antara lain meliputi beberapa hal berikut: 1) Rekrutmen Warga Belajar, 2) Pelaksanaan pengabdian masyarakat, dan 3) Penanganan pasca kegiatan, artinya mitra dalam hal ini tetap dapat memantau para peserta kegiatan walaupun sudah berakhir guna untuk melihat perkembangan yang terjadi.

\subsection{Tahap Evaluasi dan Pasa Kegiatan}

Tahapan akhir pada kegiatan ini yaitu evaluasi kegiatan pasca pelaksanaan. Kegiatan pengabdian masyarakat ini diharapkan mampu memberikan hasil yang maksimal dengan out put yang berdampak bagi peserta kegiatan. Kemudian dengan dilakukannya proses evaluasi tersebut maka akan diketahui seperti apa pencapaian dari kegiatan ini, akan mendapatkan informasi untuk keberlanjutan program di tahun-tahun berikutnya dengan pengembangan yang berbeda dalam rangka membantu 
pemecahan masalah yang ada di masyarakat serta memberikan layanan kepada masyarakat melalui kegiatan pengabdian masyarakat.

Hasil dari kegiatan ini menunjukkan bahwa peserta kegiatan telah memperoleh manfaat yakni memiliki pengetahuan dan pemahaman terkait pentingnya kelompok UMKM dan kewirausahaan sosial, pentingnya pemasaran melalui online untuk meningkatkan daya jual produk, memahami dampak yang akan terjadi dari usaha sosial dan cara mengatasi masalah yang terjadi pada aktivitas UMKM. Hal tersebut dilihat dari pengamatan tim dan hasil yang dilakukan dan diskusi dari masing-masing masyarakat sebagai bahan evaluasi dari kegiatan tersebut. Artinya bahwa perlu adanya sebuah strategi kewirausahaan yang perlu di lakukan agar para pengrajin tenun songket Desa Burai dapat mendapatkan penghasilan yang maksimal. Sebagaimana bahwa strategi kewirausahaan merupakan kesesuaian kemampuan internal dan aktivitas perusahaan dengan lingkungan eksternal (Handini, 2019).

Melalui kegiatan ini, peserta menerima materi dan terlihat adanya peningkatan pemahaman dasar mengenai kewirausahaan sosial. Selama ini masyarakat memahami berusaha itu adalah pekerjaan mandiri (secara invidu) untuk memenuhi kebutuhan hidup dan keluarga sendiri. Akan tetapi, setelah diberikan pemahaman bahwa wirausaha sosial bukan hanya untuk kepentingan pribadi, tetapi bagi semua orang sehingga dapat memberikan dampak positif dari usaha yang dijalankan. Kewirausahaan sosial merupakan sebuah gerakan dengan misi sosial yang dilakukan dengan upaya guna menemukan peluang dan mengolahnya dengan inovasi yang didukung kesiapan untuk bertindak walaupun dengan sumber daya yang terbatas (Wibowo \& Nulhaqim, 2015). Kewirausahaan sosial dinilai mampu dalam menyembuhkan berbagai penyakit sosial, seperti kemiskinan, keterbelakangan, dan kesehatan masyarakat melalui konsep kewirausahaan yang bersifat inovatif dalam mengembangkan hal baru dan menjawab permasalahan yang terjadi (Wibowo et al., 2021).

\section{Kesimpulan}

Adapun simpulan dari kegiatan pengabdian masyarakat ini terlihat pada uraian berikut: (1) Kegiatan pengabdian pada masyarakat yang dilaksanakan dalam bentuk penyuluhan dan pemberdayaan terlaksana dengan baik dan lancar, meskipun tidak lepas dari beberapa hambatan dan keterbatasan dalam pelaksanaan kegiatan PPM seperti pada saat kondisi Pandemi sehingga pelaksanaannya dilakukan dengan tatap muka terbatas. (2) Para peserta cukup antusias dan bersemangat dalam mengikuti kegiatan pengabdian pada masyarakat karena tema yang disajikan aktual dan penting karena sebagian peserta belum pernah mendapatkan informasi secara rinci serta sosialisasi untuk memecahkan permasalahan tentang UMKM dan wirausaha sosial terutama pemasaran online sehingga materi-materi yang disampaikan dapat mudah terinternalisasikan pada para peserta kegiatan.

\section{Daftar Pustaka}

Efridiyanti, M., \& Cerya, E. (2021). Faktor-Faktor Penentu Produktivitas UMKM Songket. Ecogen, 4(3), 389-404.

Febriani, R. (2021). Penyuluhan Peran Digital Marketing dalam Meningkatkan Penjualan Produk Umkm Keripik Ciping Desa Sukawana Curug Kota Serang. ABDIKARYA: Jurnal Pengabdian Dan Pemberdayaan Masyarakat, 3(2), 194 - 202.

Florita, A., Jumiati, \& Mubarak, A. (2018). Pembinaan Usaha Mikro, Kecil, dan Menengah oleh Dinas KoperasiI dan UMKM Kota Padang. Jurnal Ilmu Administrasi Publik, 1(1), 143-153.

Handini, S. (2019). Pemberdayaan Masyarakat Desa dalam Pembangunan UMKM di Wilayah Pesisir. Surabaya: Scopindo Media Pustaka.

Prasetyo, D. W. (2018). Pembinaan Usaha Kecil Mikro dan Menengah (UMKM) Konveksi Desa Karobelah Kecamatan Mojoagung - Jombang. Comvice: Journal of Community Service, 2(1), 9-14. 
Shomedran. (2016). Pemberdayaan Partisipatif dalam Membangun Kemandirian Ekonomi dan Perilaku Warga Masyarakat (Studi Pada Bank Sampah Wargi Manglayang RT 01 RW 06

Kelurahan Palasari Kecamatan Cibiru Bandung). Jurnal Pendidikan Luar Sekolah, 12(2), 1-13. Tim Desa Burai. (2020). Data Profil Desa Burai Tahun 2020. Burai: Kantor Desa Burai.

Utomo, H. (2014). Menumbuhkan Minat Kewirausahaan Sosial. Jurnal Among Makarti, 7(14), 1-16. Wibowo, H., Meidita, A. N., Aulia, A., Astuti, Y. W., Ardhianty, D. A., Hutapea, A. A., \& Irfan, M. (2021). Praktik Kewirausahaan Sosial Industri Rumah Tangga Di Desa Cibodas Solokan Jeruk Jawa Barat (Sebuah Studi Kasus Menggunakan Kerangka Kanvas Model Bisnis). Jurnal Kolaborasi Resolusi Konflik, 3(1), 127.

Wibowo, H., \& Nulhaqim, S. A. (2015). Kewirausahaan Sosial (Merevolusi Pola Pikir Menginisiasi Mitra Pembangunan). In Program Manager. Sumedang: UNPAD Press.

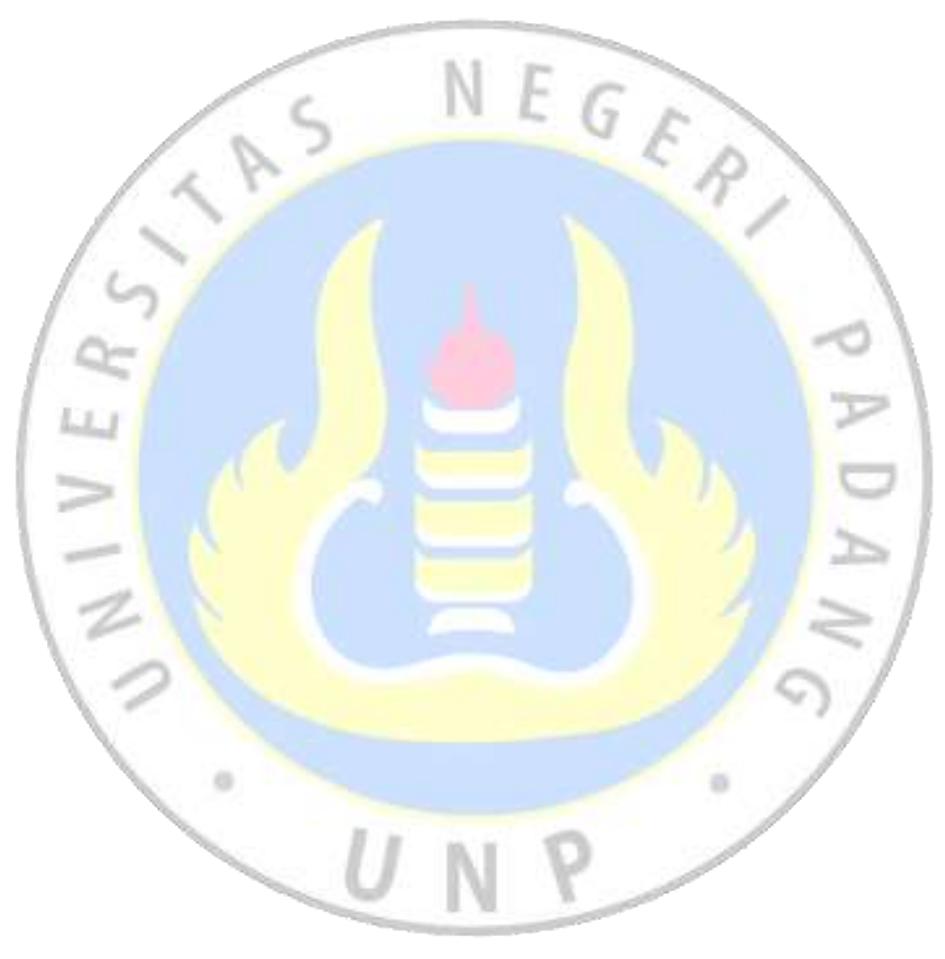

